\title{
USEFUL ANACHRONISMS: THE RWANDAN ESOTERIC CODE OF KINGSHIP
}

\author{
Jan VANSINA \\ UNIVERSITY OF WISCONSIN-MADISON
}

Any mention in a text to something demonstrably more recent than its attributed date of composition is an anachronism. The presence of an anachronism is absolute proof that the purported date given for the redaction of the final the text is wrong and that the real date occurred later than the date implied by the anachronism. In rare cases an anachronism can also occur in reverse, namely, when it can be shown that the anachronism implies the presence of something (an archaism, a practice) which had been replaced or had disappeared by the purported date for the manuscript. Anachronisms can be very useful both to date a document and in some cases to show us something about the dynamics involved in the creation of a text. The detection of anachronisms is common with regard to written documents, but they can also be used for the study of oral documents which have been memorized word by word, especially when only one version of such documents has survived. That is the case for the Rwandan esoteric code of kingship, which yields an excellent example of how a systematic search for anachronisms throws light on such a document and allows a historian to use its contents with much greater confidence than was the case otherwise.
\end{abstract}

Ubwiiru is the name given in Rwanda to a set of eighteen pieces in prose, called "roads" or "ways," which vary in length between $\mathbf{7 4}$ and 1252 lines and were learned by heart since "immemorial times" by specialists called abiiru. They contain an "how to" secret account of the liturgies for the eighteen rituals of kingship in Rwanda, each piece being devoted to one ritual. The whole includes different periodical or occasional fertitility rituals, rituals of war, and rituals about the succession to kingship. The whole "code" was recorded in writing

History in Africa 27 (2000), 415-421. 
by Alexis Kagame in 1945, but kept secret.' In 1961 a typed manuscript containing seventeen of the eighteen pieces was given to Marcel d'Hertefelt and a text edition of these appeared in 1964, accompanied by a translation into French and commentary. ${ }^{2}$ It later transpired that this text was a copy of Kagame's original record which had been impounded by Belgian military authorities ${ }^{3}$ but the copy is not perfect to the letter as the longest way here counts only 1252 lines as against Kagame's 1257.4

Ubwiiru is truly remarkable. Not only is it the fullest account we have of any of the rituals of sacred kingship in use in the many kingdoms of sub-Saharan Africa, but it is the only one, even in the Great Lakes region, that details the liturgical descriptions in a text that was learned by heart. Its teaching, recitation, and transmission was closely controlled. The wording was committed to memory by a certain number of hereditary abiiru, most of whom learned only a portion of ubwiiru while a single portion of the code was usually learned by several of them independently. The four most important abiiru, assisted by kinsmen, knew the whole code.

Before king Yuhi Gahindiro (early nineteenth century), however, there were reputedly only four or five abiiru, each of whom learned at least several pieces. When "the way of fire," which deals with a ritual for kings named Yuhi was almost lost as the result of an epidemic, the court of Yuhi Gahindiro decided to multiply the number of abiiru tenfold. Knowledge of any portion of the code was absolutely secret and ensured to remain secret by the effects on the abiiru of a magic drink that would severely sanction any indiscretion. Recitation of the code was strictly controlled and the ritualist who had forgotten the exact wording of a passage for which he was responsible was drowned, although no case is remembered where this sanction was actually imposed.' In sum, no other oral tradition in the world is known to have been so carefully commirted to memory and so tightly controlled as to transmission and recitation."

If all this were true, then the transmission of this body of tradition would be so perfect as to make ubwiiru the equivalent of a written text dated to the moment of composition of each of its components.'

\footnotetext{
'A. Kagame, "Le code ésotériçue de la dynastie du Rwanda," Zaire I(1947), 36.8-86. "Marcel d'Hertefelt and A. Coupez, La royauté sacrée de l'ancien Rivanda (Tervuren, 1964).

"Marcel d'Hertefelt, A. Coupez, and A. Kagame, "A propos du code ésotérique de l'ancien Rwanda," Africa-Terunren 14/4(1968), 117, 119; F. Gasarabive Laroche Le geste ruvanda (Paris, 1978), 44.5.

${ }^{4}$ Hertefelt/Coupez, Royauté, 1

'Ilbid., 1-7.

Jan Vansina, Oral Tradition as History (Madison, 1985), 14, 16, 42.

'But sec Vansina, L'évolution du royanme ruanda des origines à 1900 (Brussels, 1962), 27.31.
} 
Even though this does not apply to the equally esoteric commentaries or inteckerezo which accompanied the pieces and were known to the most eminent abiiru, because these were not comınitted to memory word by word, still, ubwiiru itself could be used word for word as information stemning from hoary antiquity just like a written text. ${ }^{x}$ So far no one has hazarded a guess as to the exact dates of the composition of the various pieces, but the latest of these, IX, is said to have been introduced from Burundi under Mutara Seemugeshi, well before $1700 .^{9}$ All the others are thought to be centuries earlier.

\section{III}

But is this literally true? Is ubwiiru a genuine text, unchanged since the composition of its ways? This is where a search for anachronisms comes in. To begin with, a critical reader is already alerted when told that ubwiiru, unlike Rwandan dynastic poetry, contains absolutely no archaisms. "At the very least then this means that "word by word" is not true. The text has been modernized as needed. Secondly, a check of the personal names of kings mentioned in the code (by using the index of the text edition) reveals something else. In IX 999-1004 one finds a list of kings in the order of their rule-Ndabarasa, Sentaabyo, Gahindiro, Rwogera, Rwabugiri, and Musinga-and this list recurs later in the same piece. Moreover one also finds a list of the names of the queen mothers from Sentaabyo onwards (IX, 1119-23). Ndabarasa died in 1796, Rwabugiri ruled from ca. 1865-95 and Musinga from 1896 to 1931 . So does the composition of this whole piece then date to after 1896? Not necessarily. These lists may well be an interpolation, an "updating." Just as the language has been modernized, so the names of kings would have been added. Nevertheless, this still means that the text was altered and that, as we know it, IX dates from after 1896.

Moreover, there is more to this interpolation than meets the eye. One king is omitted from this list. Rutarindwa succeeded to Rwabugiri in 1895 and was killed during a coup which brought Musinga to power in 1896." His name or mention of the coup has been suppressed in all official oral accounts ever since. He is absent in

\footnotetext{
"We only know these by the mentions made in the oeuvre of Kagame, who clearly sees these as the most trusthworty of all sources. See his Abrégé de l'ethno-bistoire du Ruvanda (Butare, 1972), 11 et passim.

"Ihid., 111-13. The chronology of the Rwandan kings adopted here is explained in the "supplément 1999" added to Vansina, Evolution (2d. ed.: Brussels, 2000). No firm dates at all should be atrributed to kings before Yuhi Mazimpaka, who ruled in the earlicr eighteenth century.

'Hertefelt/Coupez, Royauté, 14.

"See Kagame, Abrégé, 105-28 for this king.
} 
the royal genealogy, absent in dynastic poetry, and absent in official narratives. Clearly, here too his name has been suppressed.

And there just could be a little more. Elsewhere, in IX 559-60, one mentions the drums Mpatsibihugu and Kiraagutse, both created by Rwabugiri. ${ }^{2}$ Another later interpolation? Possibly. But why not mention other drums made by his predecessors? Thus Ndabarasa, who is much mentioned in IX, created Rugiramasango, but that drum is not mentioned. Why not? Could it be because that drum was destroyed during the coup? Could other drums also have been omitted for the same reason? Whatever the case, it is clear that more than innocent "updating" has been happening and that this has permeated other passages than enumerations, at least in IX.

So far so good for the hypothesis of an occasional interpolation, but they will not easily account for the following. As part of the instructions for the ritual, XV, 196-98 reads: "if its skin has aged/ they cover it with that of a cow of the 'language' herd coming from 'at Rwangainpuhwe's'." Rwangampuhwe was a chief installed in $\mathbf{1 9 0 5}$ and dismissed in 1916, and the text clearly refers to his territory. This is no mere interpolation, but can only be a blatant anachronism for such a supposedly old text.

The only explanation is that XV as it stands was memorized between 1905 and 1916. Again III, 37 has "at Mwijuka's" in its instruction as to from where to fetch a cow. Mwijuka was the chief of Kabuye in Kibali under Musinga (1896-1931) and was deposed before 1916. ${ }^{13}$ This piece was therefore memorized in the decade or so before 1916. So III and XV do not go back to hoary antiquity and we cannot date any information in them in a trustworthy fashion to before say 1900 without further corroboration.

The other pieces can also be dated by looking for the most recent visible anachronisms as shown by the mention of king's personal names, those of armies or cattle herds created by them, by their queen mothers, and by their drums. The results are as follows, although it should be noted that this is based on visible anachronisms only. The last redaction of any of these ways could in fact be younger than shown here, but it could not be older.

IV, V, VII, XII, XIV: under Ndabarasa before 1796 (probably after $c a$. 1785).

II: early 1800 s.

"'The "anthropological index" in Hertefelt/Coupez, Koy'aute, lists not just persons, but all the proper names listed in the rext, including those that do not refer to persons but, e.g., to of drums, armies, cattle herds, etc., including what other information is known among thein. Hence it is not necessary here to ammotate each proper name discussed separately.

"Historique et chronologie du Ruanda ([Kalogayi, 1956]), 157-58. 
I, VIII: ca. 1850 under Rwogera.

VI, X, XIII, XVII: under Rwabugiri (1865-1895).

IX, XI, XVI: under Musinga (after 1896)

III: before 1916

XV: $1905-1916$.

So could it be that ubwiiru was in fact never learned by heart as occurs elsewhere in sub-Saharan Africa, and that the wording of the texts dates from 1945, when Kagame took them down by dictation? That is not possible because the same passages "at so-and-sos" which date pieces III and XV to before 1916 also make clear that they had been memorized before 1916. After 1916 one would designate chiefdoms by the names of the current chiefs, not former ones. Is it possible that king Musinga, impressed by the authority of writing, had them all memorized some time after European contact, i.e., after 1900 ?

\section{IV}

To evaluate these ideas about the date of composition, we should now diligently look for anachronisms in the other direction, that is, items that must be earlier than 1900 and that would make no sense later on. And there is at least one telling case. It concerns the drum Rugiramasango, where the king says: "Here is the drum Rugiramasango" (IV, 19) and two lines later the way instructs "Rugiramasango goes to the public place" (IV, 21). But Rugiramasango was destroyed during the coup d'etat of 1896, so these lines had to be memorized before then (but after the drum was created by Ndabarasa). By itself, this passage proves that some word-for-word memorization of these rituals was already practiced in the nineteenth century, before Rwandans knew much about any writing.

We can only speculate as to why Rwandans, unlike their neigh. bors, memorized ritual word by word. Bureaucratic formalism, associated with centralizing tendencies, a need to insulate esoteric information, and a strong belief in the supernatural power inherent in words and their utterance, may all have been involved. Still one must remember that the anachronisms in III and XV show that the wording of some passages had been changed, no doubt to "update" them. Hence we conclude that memorization of ubwiiru was practiced in the nineteenth century, but that some words or expressions could be changed when need be.

Another passage contains an anachronism which does suggest a date for a whole piece. I, the ritual to cope with droughts, start as follows "When the way of Rukungugu rages" in which Rukungugu is a personification of dust. In fact it is the personal name given to a par- 
ticularly devastating drought which occurred around 1800 in Rwanda, as well as in Burundi. In Rwanda this was the year when a court faction proclaimed the baby Gahindiro as king. The end of the drought was seen as supernatural proof that the king was indeed legitimate. ${ }^{14}$ While the name Rukungugu is proof that $I$ is not earlier than $c a .1800$, its mention in the very first line of the piece suggests that it was developed during the reign of Gahindiro in the first half of the nineteenth century. One might even reason that this passage had to be memorized before the next devastating named drought hit, presumably a decade later or so." This argument is weak, however, because the association of the end of a drought with the succession of a king and his legitimacy is very strong. Hence one can only say that I was composed and memorized during the nineteenth century and probably during the reign of Gahindiro, well before 1850 .

\section{VI}

When then were all the pieces composed and memorized? All of them except III mention in their instructions the ritual quarter at the cours called "At Cyirima," where a good deal of ritual action occurs. ${ }^{16}$ This quarter was so named some time after the death of Cyirima Rujugira (ca.1780?). Hence they were all composed and memorized after that date. IV, and probably all the others also, were created before 1896 at the latest. In short, the whole ubwiiru seemingly dates from the nineteenth century. When we recall that Gahindiro is said to have multiplied the number of abiiru by ten, we may now speculate that one reason for doing so was his attempt to have all the liturgies transmitted by heart. Later, and until 1916 at the latest, the wording and content of the ubwiiru were "updated," some tampering being included in the updating.

How much tampering? We cannot know. On the one hand, the whole body of ritual surrounding the Nyiginya kings, as well as the later written record, ${ }^{17}$ shows how deeply convinced Rwandans were that these rituals were matters of the gravest importance for their country and had to be scrupulously respected, a respect which the abiiru, whose status and livelihood depended on them, fostered as nuch as they could. On the other hand, rituals might well have

\footnotetext{
'Hertefelt/Coupez, Royauté: 280; Jan Vansiun, La légende du passé (Tervureu, 1972), 133. The fire is linked to this drought.

"Kagamc, Abrégé 1972, 188, for a major drought in Gisakal around mid-century, once again associated with the arrival of a new king. Historique, 12, mentions that several severe droughts occurred during Rwabugiri's reign and datcs one in 1890 and the worst one to 1895, the year when the king died and Rutarindwa succeeded.

"Hertefelt/Coupez, Royauté, 454.

1"See Alison Des Forges, "Defear is the Only Bad News: Riwanda Under Musiingn, 1896-1931" (l'hD., Yale University, 1972), 29 et passim.
} 
changed over time, at least in detail, for reasons of supposed efficiency or by expanding or contracting as various descent groups among the abiiru sought to enhance their roles.

All in all, one expects rather little tampering. ${ }^{18}$ The strict control over the recitations was not just a façade. The rituals should be efficacious, their legitimacy guaranteed, and unilateral innovations by one or other group of abiiru should not occul: But this control also made it easy to ensure that the recitations would totally conform to the strict political dictates of the court, such as was the case with Rutarindwa. Yet because the court also believed in the efficacy of the rituals and their power to harm transgressors, such dictates must have been very rare. One may well safely conclude then that the ubwiiru as published faithfully reflect mid- to late-nineteenth-century beliefs and practices, despite the fact that some of its wording has changed since then.

\section{VII}

This approximate dating of ubwiiru by the use of anachronisms is very useful because it now allows the historian to exploit its contents. Ubwiiru, which is a very extensive text, now becomes a very valuable source, a cornucopia of information, much of which is not available through other sources. It contains not only the fullest description of rituals of sacred kingship probably anywhere in sub-Saharan Africa, but it is the earliest as well. It reveals the ritual and political geography of the nineteenth century in detail; it gives some information about political statuses and hierarchies; it contains a mass of information about agricultural and pastoral practices and problems; it informs us about religious beliefs, attitudes, and practices beyond the purely royal rituals; and it tells us much about the historical consciousness of the Rwandan court by the mid- or late nineteenth century. Thus ubwiiru abundantly proves the fruitfulness of a systematic search for anachronisms.

\footnotetext{
"In contrast, for instance, to the politically highly-charged official account of royal successions. Cf. J-N Nkurikyimfura, "La révision d'une chronologie: le cas du royaume du Rwanda" in C.-H. Perrot, ed., Sources orales de l'histoire de l'Afrique (Paris, 1989),149-80. This author shows extensive manipulation of the supposed ancestry of certain queen mothers. In addition, I have grave doubts about the reliability of the whole list before Yuhi Mazimpaka.
} 